\title{
Nuts: source of energy and macronutrients
}

\author{
Gemma Brufau, Josep Boatella and Magda Rafecas* \\ Nutrition and Food Science Department - CeRTA, University of Barcelona, 08028 Barcelona, Spain
}

\begin{abstract}
On the basis of the high fat content of nuts, they are traditionally considered as foods that provide a high amount of energy. However, epidemiologic and clinical observations do not indicate an association between nut intake and increased BMI. There is a notorious variability in macronutrient composition among nuts, although they have some consistent patterns. Nuts contain all major macronutrients: protein, carbohydrate, and fat. The total protein content is relatively high, which makes them a good source of plant protein (especially for vegetarians). Although nuts contain low amounts of some essential amino acids, this is not a nutritional concern due to the complement of protein. In addition, nuts have a low lysine:arginine ratio, which is inversely associated with the risk of developing hypercholesterolemia and atherosclerosis. Carbohydrates are the second highest macronutrient in nuts in terms of total calories provided. The fat fraction is characterized by a high amount of unsaturated fatty acids and a low content of saturated fatty acids. In conclusion, the high content in unsaturated fatty acids, the low lysine:arginine ratio, and the presence of other bioactive molecules (such as fibre, phytosterols, vitamin and other antioxidants, and minerals) make the addition of nuts to healthy diets a useful tool for the prevention of cardiovascular heart diseases.
\end{abstract}

As we define them today, tree nuts (almonds, Brazil nuts, cashew, hazelnuts, macadamia nuts, pecans, pine nuts, pistachios and walnuts) originate from Anatolia. From there, the cultivation of tree nuts was introduced in Greece, then in Italy during the Roman Empire, and finally it was extended to all of Europe during the Middle Ages. The growing of tree nuts was introduced in America in the 16th century (Lemoine, 1998). Nuts are part of the Mediterranean diet, although their per capita consumption is relatively low (2-9 kg/year). Traditional Mediterranean nuts include almonds, hazelnuts, walnuts, peanuts and pistachios. Typically in Mediterranean diets, nuts are incorporated into many dishes, such as snacks (roasted and salted almonds, hazelnuts, and pistachios), sauces ('romesco' and 'pesto'), cold soups, such as 'ajoblanco' in Spain, cakes, pastries, and cookies ('turrón', 'nougat', walnut cakes, 'menjar blanc', 'amaretti'). Because of their high-energy content, nuts have been introduced into sports snacks and supplements.

With today's busy lifestyles, nuts are a convenient, tasty and easy snack that contributes to a healthy lifestyle. In addition to their tastiness, tree nuts and peanuts are both cholesterol-free and rich in important nutrients, including vegetable protein, fibre and unsaturated fatty acids. They also contain relevant micronutrients, such as folic acid, niacin and vitamins $\mathrm{E}$ and $\mathrm{B}_{6}$, and minerals such as magnesium, copper, zinc, selenium, phosphorus and potassium.

Nuts are part of the US Food Guide Pyramid and Mediterranean Diet Pyramids. Experts recommend eating a variety of foods from the five food groups every day in order to obtain the nutrients you need. Nuts fall into the 'Meat, Poultry, Fish, Dry Beans, Eggs and Nut Group' and can be eaten every day. The recommended number of servings from this group is 2-3 per day. One-third of a cup of nuts or two tablespoons of peanut butter contain the same energy as a one-ounce serving of cooked lean meat.

Nuts also have a low water content, with water activity $\left(\mathrm{a}_{\mathrm{w}}\right)$ between 0.6 and 0.7 . While the low water content of nut helps to preserve them for long periods of time, the high unsaturated fat content increases their chances of becoming rancid, especially during roasting, and this leads to a loss of flavour during storage.

Since nuts are high in fat and therefore energy-dense, consumers regard them as fattening foods. However, while they are rich in energy they are also rich in many healthful nutrients such as unsaturated fatty acids, vitamins, minerals, and non-nutrients such as phytosterols and a host of phytochemicals that have health promoting benefits to humans.

\section{Energy}

Table 1 shows the total energy content of nuts. Brazil nuts, pecans, and macadamia nuts are richest in fat and energy, followed by almonds, walnuts, hazelnuts and pine nuts. Pistachios and cashews are the nuts with the lowest energy content.

According to the energy density (ratio between energy content in kcal and weight), foods can be classified into four groups: a) very low energy density foods $(<0.6 \mathrm{kcal} / \mathrm{g})$; b) low energy density foods $(0.6-1.5 \mathrm{kcal} / \mathrm{g}) ; \mathrm{c})$ medium energy density foods $(1.5-4 \mathrm{kcal} / \mathrm{g})$, and d) high energy density foods $(>4 \mathrm{kcal} / \mathrm{g})$. Nuts are high energy density foods and their consumption could contribute to a high energy intake and weight gain. The explanation for the excess consumption of fat could be the fact that sensory-specific satiety has been shown to be affected by the amount of food rather than the energy content (Rolls et al. 1999). 
Table 1. Energy content of nuts

\begin{tabular}{lccccc}
\hline & \multicolumn{2}{c}{ Raw } & & \multicolumn{2}{c}{ Roasted } \\
\cline { 2 - 3 } \cline { 5 - 6 } & $\begin{array}{c}\text { Energy } \\
(\mathrm{kcal})\end{array}$ & $\begin{array}{c}\text { Energy } \\
(\mathrm{kJ})\end{array}$ & & $\begin{array}{c}\text { Energy } \\
(\mathrm{kcal})\end{array}$ & $\begin{array}{c}\text { Energy } \\
(\mathrm{kJ})\end{array}$ \\
\hline Almonds & 581 & $2 \cdot 431$ & & 607 & 2.541 \\
Brazil nuts & 656 & 2.743 & & - & - \\
Cashew nuts & 553 & $2 \cdot 314$ & & 574 & 2.402 \\
Hazelnuts & 629 & $2 \cdot 630$ & & 646 & 2.703 \\
Macadamia nuts & 718 & 3.004 & & 718 & 3.005 \\
Pecans & 691 & $2 \cdot 889$ & & 715 & 2.990 \\
Peanuts & 567 & 2.374 & & 581 & 2.431 \\
Pine nuts & 629 & 2.632 & & - & - \\
Pistachios & 557 & 2.332 & & 568 & 2.376 \\
Walnuts & 618 & 2.584 & & - & - \\
\hline
\end{tabular}

Source: US Department of Agriculture Nutrient Data Base at http://www.nal.usda. gov/fnic/cgi-bin/nut_search.pl

However, as discussed by Rajaram \& Sabaté (2006) in this supplement, available data suggest that adding nuts to the habitual diets of free-living individuals does not induce weight gain and may even help lose weight. Garcia-Lorda et al. (2003) and Sabaté (2003) suggest several hypotheses which may explain this fact. First, the absorption of energy from nuts is incomplete, probably due to the structure of lipid-storing granules with incomplete release of fatty acids during digestion (Ellis et al. 2004), or to various fibre components. Second, it is suggested that nuts exert a satiating effect due to components such as fibre, whose role in energy intake has been discussed at length (Marlett et al. 2002). Third, nuts may increase resting energy expenditure and diet-induced thermogenesis because of their high-protein content and high polyunsaturated-to-saturated-fatty acid ratio (Jones et al. 1992), and this may result in less fat deposition.

When nuts are roasted with oil, there is an increase in their total energy content (Table 1). Because of oil absorption, total energy increases by an average of $30-40 \mathrm{kcal} / 100 \mathrm{~g}$ in oilroasted nuts. The nutritional value of the final product is linked to the quality of the oil used and to the technological treatment employed. Both factors can modify the fatty acid profile of nuts.

\section{Protein}

The total protein content of some nuts is relatively high, making them a good source of plant protein (Table 2). Peanuts, walnuts, almonds, pistachios and cashews have the highest protein content, followed by Brazil nuts, hazelnuts and pine nuts. Pecans and macadamia nuts have the lowest protein content. The protein fraction decreases in roasted nuts due to the increase in the fat content.

Even though the total amount of protein in nuts is high, the biological value of nuts is not very high since they are limiting in some essential amino acids. The amino acid composition of walnuts and hazelnuts are compared to that of a whole egg in Figs. 1 and 2. In general, for all nuts, threonine is the limiting amino acid. Threonine is present in nuts in the range of $25-40 \mathrm{mg} / \mathrm{g}$ of protein compared to $44 \mathrm{mg} / \mathrm{g}$ of protein in a whole egg. Brazil nuts are poorest and cashews are richest in threonine. The tryptophan content of all nuts is quite similar and close to that of whole eggs, with the exception of
Table 2. Carbohydrate $(\mathrm{CHO})$, protein, and fat content of nuts $(\mathrm{g} / 100 \mathrm{~g}$ of raw and roasted product)

\begin{tabular}{|c|c|c|c|c|c|c|}
\hline & \multicolumn{3}{|c|}{ Raw } & \multicolumn{3}{|c|}{ Roasted } \\
\hline & $\mathrm{CHO}^{*}$ & Protein & Fat & $\mathrm{CHO}^{*}$ & Protein & Fat \\
\hline Almonds & 19.9 & 21.9 & $50 \cdot 6$ & $17 \cdot 7$ & $21 \cdot 2$ & $55 \cdot 2$ \\
\hline Brazil nuts & $12 \cdot 3$ & $14 \cdot 3$ & $66 \cdot 4$ & - & - & - \\
\hline Cashews & $30 \cdot 2$ & $18 \cdot 2$ & $46 \cdot 4$ & 29.9 & $16 \cdot 8$ & $47 \cdot 8$ \\
\hline Hazelnuts & $17 \cdot 0$ & $13 \cdot 7$ & $60 \cdot 8$ & $17 \cdot 6$ & $15 \cdot 0$ & 62.4 \\
\hline Macadamia nuts & $13 \cdot 8$ & 7.9 & $75 \cdot 8$ & 13.4 & $7 \cdot 8$ & $76 \cdot 1$ \\
\hline Pecans & $13 \cdot 9$ & $9 \cdot 2$ & $72 \cdot 0$ & $13 \cdot 0$ & $9 \cdot 2$ & $75 \cdot 2$ \\
\hline Peanuts & $16 \cdot 1$ & $25 \cdot 8$ & $49 \cdot 2$ & $18 \cdot 9$ & $26 \cdot 4$ & $49 \cdot 3$ \\
\hline Pine nuts & $19 \cdot 3$ & $11 \cdot 6$ & $61 \cdot 0$ & - & - & - \\
\hline Pistachios & $28 \cdot 0$ & $20 \cdot 6$ & $44 \cdot 4$ & $26 \cdot 8$ & $21 \cdot 4$ & $46 \cdot 0$ \\
\hline Walnuts & 9.9 & $26 \cdot 1$ & $65 \cdot 2$ & - & - & - \\
\hline
\end{tabular}

*By difference (total energy minus energy from fat and protein).

Source: US Department of Agriculture Nutrient Data Base at http://www.nal.usda. gov/fnic/cgi-bin/nut_search.pl

macadamia nuts, which have less tryptophan (around $8 \mathrm{mg} / \mathrm{g}$ of protein) than other nuts. Nuts are low in isoleucine, with a content ranging between 32 and $40 \mathrm{mg} / \mathrm{g}$ of protein. This contrasts with the total isoleucine content of whole egg of $54 \mathrm{mg} / \mathrm{g}$ of protein. For this amino acid, almonds show the least amount $(32 \mathrm{mg} / \mathrm{g}$ of protein) and cashews the most $(43 \mathrm{mg} / \mathrm{g}$ of protein). The total amount of leucine is almost similar to that of whole eggs, around $86 \mathrm{mg} / \mathrm{g}$ of protein. Pistachios and pecans have the lowest content of leucine, around $65 \mathrm{mg} / \mathrm{g}$ of protein.

As shown in Table 3, the dibasic amino acid lysine, which is in deficit in many foods, is also poor in most nuts and considerably lower than in whole eggs $(70 \mathrm{mg} / \mathrm{g}$ of protein). The sulphur amino acids, such as methionine and cysteine, are also found in low amounts in nut protein. The exception is Brazil nuts, which contain $96 \mathrm{mg} / \mathrm{g}$ of protein of total sulphur amino acids, an amount higher than in whole eggs $(57 \mathrm{mg} / \mathrm{g}$ of protein). Other amino acids such as phenylalanine and tyrosine are present in significant amounts in the protein of all nuts. The content of valine is quite important. Quantitatively, cashew nuts provide $60 \mathrm{mg} / \mathrm{g}$ of protein, whereas whole eggs provide $68 \mathrm{mg} / \mathrm{g}$ of protein. Almonds provide the lowest total amount of valine, with a content of $38 \mathrm{mg} / \mathrm{g}$ of protein. Finally, the content of histidine is quite high for nuts overall, pistachios being the only nuts having a lower amount $(21 \mathrm{mg} / \mathrm{g}$ of protein) than whole eggs $(24 \mathrm{mg} / \mathrm{g}$ of protein).

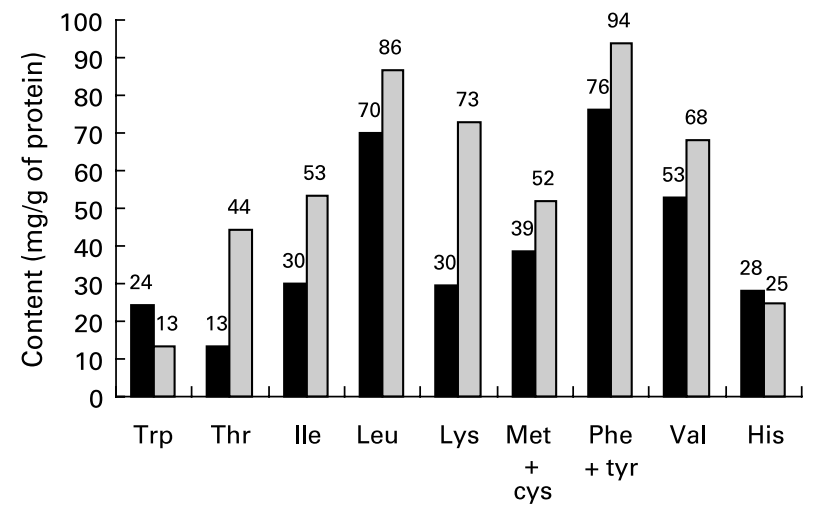

Fig. 1. Essential amino acids (mg/g protein) of walnut protein compared with egg protein. $\mathbf{\square}$, Walnuts; 䛜, Egg 




Fig. 2. Essential amino acids (mg/g protein) in hazelnut protein compared with egg protein. $\mathbf{\square}$, Hazelnuts; 圈, Egg.

Looking at the amino acid composition of nuts, it can be said that their protein profile is suboptimal because one or more essential amino acids are present in small amounts. Therefore, for the body to make good use of proteins, nuts need to complement other food proteins. Strict vegetarian diets that are rich in nuts can be supplemented with pulses or other vegetables and with dairy products in order to provide a high protein value.

The protein and amino acid content of nuts also varies depending on the different cultivars. Savage (2001) found some differences in the total protein content of walnuts from various New Zealand cultivars. Another example of the differential protein content of walnuts is that the European commercial cultivar G139 shows the highest protein content ( $16.8 \mathrm{~g} /$ $100 \mathrm{~g}$ ), while the US Tehana cultivar shows the lowest protein content $(13.6 \mathrm{~g} / 100 \mathrm{~g})$.

Intake of plant protein has been associated with a low cardiovascular risk compared to that of animal protein. Part of the explanation for this association may be the lysine to arginine ratio of plant protein (Kritchevsky, 1990). In general, vegetable proteins such as those in nuts are rich in arginine and poor in lysine, whereas the opposite occurs in meat and dairy products. The risk of developing hypercholesterolaemia and atherosclerosis is higher with foods that have a high lysine:arginine ratio (Carroll \& Hamilton, 1975; Kritchevsky et al. 1982; Sugano et al. 1984; Kritchevsky, 1990).

Arginine is the precursor of nitric oxide (NO), an endogenous vasodilator and an important mediator of homeostatic processes

Table 3. Arginine and lysine content ( $\mathrm{g} / 100 \mathrm{~g}$ of protein) and their ratio in nuts

\begin{tabular}{lccc}
\hline & Arginine & Lysine & Lys:Arg ratio \\
\hline Almonds & 116.0 & 28.3 & 0.24 \\
Brazil nuts & 150.0 & 35.4 & 0.23 \\
Cashews & 116.5 & 50.9 & 0.44 \\
Hazelnuts & 147.9 & 28.1 & 0.19 \\
Macadamia nuts & 177.2 & 22.8 & 0.13 \\
Pecans & 128.4 & 31.3 & 0.24 \\
Peanuts & 119.6 & 35.9 & 0.30 \\
Pine nuts & 194.6 & 37.5 & 0.19 \\
Pistachios & 82.4 & 46.8 & 0.57 \\
Walnuts & 150.4 & 29.6 & 0.20 \\
\hline
\end{tabular}

Source: US Department of Agriculture Nutrient Data Base at http:// www.nal.usda.gov/fnic/cgi-bin/nut_search.pl and host defense mechanisms (Moncada \& Higgs, 1993; Faxon et al. 2004). Arginine is required by the constitutive enzyme endothelial NO synthase to produce NO. Administration of this amino acid improves endothelial function in animal models and in humans with hypercholesterolemia and atherosclerosis (Gornik \& Creager, 2004). It has been hypothesized that the decreased coronary heart disease risk observed in association with frequent nut intake in epidemiological studies, reviewed by Kelly \& Sabaté (2006) in this supplement, may be due in part to the high arginine content of nuts leading to enhanced synthesis of NO (Cooke et al. 1993; Feldman, 2002). The lysine:arginine ratio of nuts is quite low. Hazelnuts, pine nuts and walnuts have the lowest ratios $(0 \cdot 19-0 \cdot 20)$; pecans, Brazil nuts and almonds have ratios of $0 \cdot 23-0 \cdot 24$, and the highest ratios are found in pistachios and cashews $(\approx 0.5)$ (Souci et al. 2000). Such ratios are much lower than those present in animal proteins such as casein (1.9) and whole milk (2.4), and even in soy protein (0.58-1.0) (Kritchevsy et al. 1982). Thus, nut protein has a lysine:arginine ratio that is potentially more beneficial than that of soy protein.

The insulin:glucagon ratio has been used as an early metabolic index of the effect of dietary proteins on serum cholesterol levels, a risk factor for cardiovascular diseases (Sanchez \& Hubbard, 1991). Therefore, taking into account that plant proteins (such as those contained in soy and nuts) are richer in arginine and glycine than animal proteins (such as casein), and that the postprandial insulin:glucagon ratio is affected by postprandial plasma amino acids (Sanchez et al. 1988; Calbet \& MacLean, 2002), it is suggested that foods rich in protein (such as nuts), with a high content in arginine and glycine, may reduce the risk of chronic degenerative diseases by their influence on insulin and glucagon levels (Hubbard et al. 1989; KrajcovicovaKudlackova et al. 2005).

\section{Carbohydrate}

The total carbohydrate content of nuts is provided in Table 2. The lowest amounts are found in walnuts, and progressively increasing amounts occur in Brazil nuts, pecans and Macadamia nuts, almonds and pine nuts, pistachios and, finally, cashews. Different composition tables, however, may show different amounts of carbohydrate for specific nuts depending on whether the carbohydrate content has been actually determined or calculated.

Recent data (Luscombe et al. 2002, 2003; Layman et al. 2003) suggest that some undesirable effects of low-carbohydrate diet may be counteracted by a higher protein intake, as high protein diets have been shown to induce favourable effects of feelings on satiety and hunger, help preserve lean body mass, effectively reduce fat mass and beneficially impact on insulin sensitivity and the blood lipid status. Therefore, the nutritional composition of nuts, rich in protein and low in $\mathrm{CHO}$, make them a suitable food for incorporating into diets intended for weight loss and weight control (Adam-Perrot et al. 2006).

\section{Fat}

Total fat is the main fraction in nuts. As shown in Table 2, the total fat content per $100 \mathrm{~g}$ ranges from $44.4 \mathrm{~g}$ in pistachios to $75.8 \mathrm{~g}$ in macadamia nuts. Again, the geographic origin of 
different tree nut cultivars can result in variations of fat content. Parcerisa et al. (1993) studied Spanish hazelnut varieties, such as 'Pauetet', 'Gironell' and 'Negret', and reported that the geographic origin and the climatic conditions modified the fat content. For instance, for the 'Negret' variety, the authors showed a difference of $8 \%$ in fat content depending on location, even within the same geographical area (Reus or Falset in Tarragona, Spain). This variability affects fatty acid composition as well, especially the proportions of oleic and linoleic acids. Triacylglycerol content, especially triolein, and vitamin $\mathrm{E}$ and mineral content are also affected by variety and geography. This variability may cause changes in the stability of nuts, especially during storage. On the other hand, the technological treatment applied to nuts can also modify the lipid content and the fatty acid composition. As discussed, oil roasting increases the fat content by approximately $4 \%$, due to dehydration occurring during the procedure and both adsorption and absorption of oil used for roasting. This is important because it may change the nutritional value of the lipid fraction of nuts, and special attention must be paid to the quality of the oil used in the roasting and frying processes.

The favourable fatty acid composition of nuts is discussed in detail by Ros \& Mataix (2006) in this supplement. Nuts are characterized by a high content of MUFA and PUFA, and proportionally, less SFA. The predominant type of unsaturated fatty acid in most nuts is MUFA, contributing on average $62 \%$ of the energy from fat. Together, MUFA and PUFA contibute around $91 \%$ of the energy from fat (Kris-Etherton et al. 1999). Parcerisa et al. (1998) studied different varieties of hazelnuts from Oregon, and found relevant difference in fatty acid composition. For instance, the content of PUFA in that study ranged from $8.7 \%$ in the Italian variety 'Tonda Romana' to $18 \%$ for the Turkish variety 'Tomboul'.

A large number of studies (Sabaté 1993, 1999; de Lorgeril et al. 1999, 2001) suggest that nuts may play an important role in reducing the risk for cardiovascular diseases. In one study (Albert et al. 2002), researchers found that, although the benefits were greatest for frequent nut eaters, those who ate nuts even twice a week had a $47 \%$ lower risk of sudden cardiac death and a $30 \%$ lower risk of total coronary heart disease than those who rarely or never consumed nuts. Nuts, particularly walnuts, contain n-3 fatty acids, which have been shown to elicit cardioprotective effects due in part to reduced platelet aggregation and vasoconstriction (Kaminski et al. 1993) and favourable effects on blood coagulation via fibrinolysis (Barcelli et al. 1985) and blood clot formation (Shahar et al. 1993).

In the summer of 2004, the FDA accepted a qualified health claim for nuts and nut-containing products because of the link of nut consumption with a reduced risk of heart disease. The nut products which meet the FDA's criteria may be labelled as follows: 'Scientific evidence suggests but does not prove that eating 1.5 ounces per day of most nuts as part of a diet low in saturated fat and cholesterol may reduce the risk of heart disease'.

In addition to the distinctive fatty acid profile of nuts, they are good sources of several other important nutrients. Nuts are a source of phytosterols and other phytochemicals, including ellagic acid, flavonoids, phenolic compounds, luteolin and tocotrienols. Other micronutrients present in notable quantities in most nuts include thiamine, niacin, riboflavin, selenium, potassium and iron. Therefore, the constituents of nuts may contribute to their beneficial health effects through several mechanisms.

\section{Acknowledgements}

The authors would like to thank the important help and advice given by Dr Jordi Salas-Salvadó (Unitat de Nutrició Humana, Facultat de Medicina de Reus, Universitat Rovira i Virgili), and from Nucis Foundation Health and Tree Nuts.

\section{References}

Adam-Perrot A, Clifton P \& Brouns F (2006) Low carbohydrate diets: nutritional and physiological aspects. Obes Rev 7, 49-58.

Albert CM, Gaziano JM, Willett WC \& Manson JE (2002) Nut consumption and decreased risk of sudden cardiac death in the Physicians' Health Study. Arch Intern Med 162, 1382-1387.

Barcelli U, Glas-Greenwalt P \& Pollak VE (1985) Enhancing effect of dietary supplementation with omega-3 fatty acids on plasma fibrinolysis in normal subjects. Thromb Res 39, 307-312.

Calbet JA \& MacLean DA (2002) Plasma glucagon and insulin responses depend on the rate of appearance of amino acids after ingestion of different protein solutions in humans. J Nutr 132, 2174-2182.

Carroll KK \& Hamilton RM (1975) Effects of dietary protein and carbohydrate on plasma cholesterol levels in relation to atherosclerosis. J Food Sci 40, 18-23.

Cooke JP, Tsao P, Singer A, Wang BY, Kosek J \& Drexler H (1993) Anti-atherogenic effect of nuts: is the answer NO? Arch Intern Med 153, 898-899.

de Lorgeril M, Salen P, Martin JL, Monjaud I, Delaye J \& Mamelle N (1999) Mediterranean diet, traditional risk factors, and the rate of cardiovascular complications after myocardial infarction: final report of the Lyon Diet Heart Study. Circulation 99, 779-785.

de Lorgeril M, Salen P, Laporte F, Boucher F \& de Leiris J (2001) Potential use of nuts for the prevention and treatment of coronary heart disease: from natural to functional foods. Nutr. Metab Cardiovasc Dis 11, 362-371.

Ellis PR, Kendall CW, Ren Y, Parker C, Pacy JF, Waldron KW \& Jenkins DJ (2004) Role of cell walls in the bioaccessibility of lipids in almond seeds. Am J Clin Nutr 80, 604-613.

Faxon DP, Fuster V, Libby P, et al. (2004) Atherosclerotic vascular disease conference: writing group III: pathophysiology. Circulation 109, 2617-2625.

Feldman EB (2002) The scientific evidence for a beneficial health relationship between walnuts and coronary heart disease. J Nutr 132, suppl. 5S, 1061S-1102S.

Garcia-Lorda P, Megias-Rangil I \& Salas-Salvado J (2003) Nut consumption, body weight and insulin resistance. Eur J Clin Nutr 57, suppl. 1, S8-S11.

Gornik HL \& Creager MA (2004) Arginine and endothelial and vascular health. J Nutr 134, Suppl. 10, 2880S-2887S.

Hubbard R, Kosch CL, Sanchez A, Sabate J, Berk L \& Shavlik G (1989) Effect of dietary protein on serum insulin and glucagon levels in hyper- and normocholesterolemic men. Atherosclerosis 76, 55-61.

Jones PJ, Ridgen JE, Phang PT \& Birmingham CL (1992) Influence of dietary fat polyunsaturated to saturated ratio on energy substrate utilization in obesity. Metabolism 41, 396-401.

Kaminski WE, Jendraschak E, Kiefl R \& von Schacky C (1993) Dietary omega-3 fatty acids lower levels of platelet-derived growth factor mRNA in human mononuclear cells. Blood 81, 1871-1879. 
Kelly J \& Sabaté J (2006) Nuts and coronary heart disease: an epidemiological perspective. Br J Nutr, 96, suppl. 2, S61-S67.

Krajcovicova-Kudlackova M, Babinska K \& Valachovicava M (2005) Health benefits and risks of plant proteins. Bratisl Lek Listy 106, 231-234.

Kris-Etherton PM, Yu-Poth S, Sabate J, Ratcliffe HE, Zhao G \& Etherton TD (1999) Nuts and their bioactive constituents: effects on serum lipids and other factors that affect disease risk. Am J Clin Nutr 70, suppl., 504S-511S.

Kritchevsky D (1990) Protein and atherosclerosis. J Nutr Sci Vitaminol (Tokyo) 36, suppl., S81-S86.

Kritchevsky D, Tepper SA, Czarnecki SK \& Klurdfeld DM (1982) Atherogenity of animal and vegetable protein. Influence of the lysine to arginine ratio. Atherosclerosis 41, 429-431.

Layman DK, Boileau RA, Erickson DJ, Painter JE, Shiue H, Sather C \& Christou DD (2003) A reduced ratio of dietary carbohydrate to protein improves body composition and blood lipid profiles during weight loss in adult women. $J$ Nutr 133, 411-417.

Lemoine E (1998) Guide des fruits du monde: les frutis de nos régions, les variétés exotiques. Lausanne: Delachaux et Niestle.

Luscombe ND, Clifton PM, Noakes M, Parker B \& Wittert G (2002) Effects of energy-restricted diets containing increased protein on weight loss, resting energy expenditure, and the thermic effect of feeding in type 2 diabetes. Diabetes Care 25, 652-657.

Luscombe ND, Clifton PN, Noakes M, Farnsworth E \& Wittert G (2003) Effect of a high-protein, energy-restricted diet on weight loss and energy expenditure after weight stabilization in hyperinsulinemic subjects. Int J Obes Relat Metab Disord 27, 582-590.

Marlett JA, McBurrey MI \& Slavin JLAmerican Dietetic Association (2002) Position of the american dietetic Association: health implications of dietary fiber. J Am Diet Assoc 102, 993-1000.

Moncada S \& Higgs A (1993) The L-arginine-nitric oxide pathway. N Engl J Med 329, 2002-2012.

Parcerisa J, Boatella J, Codony R, et al. (1993) Influence of variety and geographical origin on the lipid fraction of hazelnuts (Corylus avellana L.) from Spain. Fatty acid composition. Food Chem 48, $411-414$.
Parcerisa J, Richardson DG, Rafecas M, Codony R \& Boatella J (1998) Fatty acid, tocopherol and sterol content of some hazelnut varieties (Corylus avellana L.) harvested in Oregon (USA). J Chromatogr A 805, 259-268.

Rajaram S \& Sabaté J (2006) Nuts, body weight and insulin resistance. Br J Nutr 96, suppl. 2, S79-S86.

Rolls BJ, Bell EA, Castellanos WH, Chow M, Pelkman CL \& Thorwart ML (1999) Energy density but not fat content of foods affected energy intake in lean and obese women. Am J Clin Nutr 69, 863-871.

Ros E \& Mataix J (2006) Fatty acid composition of nuts - implications for cardiovascular health. Br J Nutr 96, suppl. 2, S29-S35.

Sabaté J (1993) Does nut consumption protect against ischaemic Herat disease? Eur J Clin Nutr 47, suppl. 1, S71-S75.

Sabaté J (1999) Nut consumption, vegetarian diets, ischemic heart disease risk, and all-cause mortality: evidence form epidemiologic studies. Am J Clin Nutr 70, suppl., 500S.

Sabaté J (2003) Nut consumption and body weight. Am J Clin Nutr 78, suppl., 647S-650S.

Sanchez A \& Hubbard RW (1991) Plasma amino acids and the insulin/glucagon ratio as an explanation for the dietary protein modulation of atherosclerosis. Med Hypotheses 36, 27-32.

Sanchez A, Hubbard RW, Smit E \& Hilton GF (1988) Testing a mechanisms of control in human cholesterol metabolism: relation of arginine and glycine to insulin and glucagon. Atherosclerosis 71, 87-92.

Savage GP (2001) Chemical composition of walnuts (Juglans regia L.) grown in New Zealand. Plant Foods Hum Nutr 56, 75-82.

Shahar E, Folsom AR, Ku KK, et al. (1993) Associations of fish intake and dietary n-3 polyunsaturated fatty acids with a hypocoagulable profile: the Atherosclerosis Risk in Communities (ARIC) study. Arterioscler Thromb 13, 1205-1212.

Souci SW, Fachmann W \& Kraut H (2000) 6th ed. Food composition tables. Sttutgart: CRC Press.

Sugano M, Ishiwaki N \& Nakashima K (1984) Dietary protein-dependent modification of serum cholesterol level in rat. Significance of the arginine/lysine ratio. Ann Nutr Metab 28, 192-199. 